\title{
, nat \\ Influence of Parking Sheds on Energy Efficiency of Road Refrigerated Transport
}

\author{
Ludmiła Filina-Dawidowicz ${ }^{1, * \mathbb{D}}$ and Csaba Csiszár ${ }^{2}$ (D) \\ 1 Department of Logistics and Transportation Economics, Faculty of Maritime Technology and Transport, \\ West Pomeranian University of Technology in Szczecin, Ave. Piastów 41, 71-065 Szczecin, Poland \\ 2 Department of Transport Technology and Economics (KTKG), Faculty of Transportation Engineering and \\ Vehicle Engineering (KJK), Budapest University of Technology and Economics (BME), Múegyetem rkp. 3., \\ H-1111 Budapest, Hungary; csiszar.csaba@kjk.bme.hu \\ * Correspondence: ludmila.filina@zut.edu.pl; Tel.: +48-914494005
}

Citation: Filina-Dawidowicz, L.; Csiszár, C. Influence of Parking

Sheds on Energy Efficiency of Road Refrigerated Transport. Energies 2022, 15, 1883. https://doi.org/10.3390/ en15051883

Academic Editor: Amela Ajanovic

Received: 5 January 2022

Accepted: 25 February 2022

Published: 3 March 2022

Publisher's Note: MDPI stays neutral with regard to jurisdictional claims in published maps and institutional affiliations.

Copyright: (c) 2022 by the authors. Licensee MDPI, Basel, Switzerland. This article is an open access article distributed under the terms and conditions of the Creative Commons Attribution (CC BY) license (https:// creativecommons.org/licenses/by/ $4.0 /)$.

\begin{abstract}
The energy efficiency of road refrigerated transport is still a less researched area, despite a significant amount of energy being used for cooling perishable goods inside the refrigerated vehicle. The refrigeration units of these vehicles continuously operate while en route from the cargo sender to the recipient, even during the vehicle's forced stopovers due to the driver's working time limitations. This article aims to summarize the impact of the parking sheds used in rest and service areas on the energy consumption of the vehicle's refrigeration unit. The achievable cost savings by decreasing the energy consumption of the semi-trailer's refrigeration units are also presented. We establish a mathematical model to calculate the heat balance and verify our approach. The calculation results, which were carried out under certain operating conditions of the refrigeration unit of a semi-trailer, provide an opportunity to achieve savings on a scale of $12.03 \%$. Lastly, ideal locations of rest and service areas with sheds along the motorways and expressways in Poland are also proposed.
\end{abstract}

Keywords: refrigerated transport; energy efficiency; road infrastructure; cost savings; rest and service areas; heat balance; perishable cargo; shed

\section{Introduction}

The delivery of many types of goods requires controlled transport and storage conditions. The related technology is constantly developing [1]. The goods, such as food products, beverages, flowers, and medicines, are transported chilled or frozen in most cases. During road transport, these loads can be carried in refrigerated vehicles (trucks) equipped with a refrigeration unit, as well as in refrigerated trailers or semi-trailers connected to tractor units [2-4].

The haulage of cargo in refrigerated vehicles is associated with high costs, because, in addition to the direct transport costs (related to fuel consumption, etc.) the costs associated with refrigeration are significant. Research carried out by the Motor Transport Institute showed that, within the cost structure of 1 vehicle-kilometer, over $40 \%$ of the costs are related to the fuel [5]. Correspondingly, in the case of long-distance road transport of perishable goods, the share of fuel costs exceeds the total transport costs by up to $50 \%$. Therefore, an improvement of energy efficiency would significantly affect the costs of perishable cargo transport.

Due to limitations of the driver's working time [6], regular stopping and parking of vehicles is required, whereby the driver can rest at a road transport infrastructure (parking places, rest and service areas (RSA)). During this time, the refrigeration unit of the vehicle works constantly. A longer break leads to greater costs associated with cooling.

Moreover, food road transport is associated with a high level of emissions. Carrying temperature-controlled food by road emits $0.66 \mathrm{~kg}$ of carbon dioxide equivalent per metric 
ton-kilometer [7]. This is considerably higher than the emission factor of transporting foods by sea, which is between 0.01 and $0.02 \mathrm{~kg} \mathrm{CO}_{2}$ eq per metric ton-kilometer.

According to Accorsi et al. [8], as much as $15 \%$ of total worldwide energy is used by cold chain infrastructures. They stated that since $40 \%$ of food deliveries need refrigeration, the growth of global food demand and widening of the global supply chains would significantly increase the energy demand and the associated carbon emissions. The average consumption of refrigerated transport depends on many factors, including weather and cargo storage conditions, as well as the type of transport unit [9-11]. Considering the large volume of transported perishable cargo, the reduction of this consumption by just several percent can lead to significant savings.

During deliveries, a greater temperature difference between the ambient temperature and cargo transport temperature necessitates more energy to maintain the set temperature inside the vehicle's body. One of the solutions to reduce this influence is to park the refrigerated vehicles under roofing (shed) that decreases the impact of external factors on the refrigerated vehicle's operation. Such roofing (e.g., sheds) can be installed in parking lots, RSAs, and other places where vehicles are parked for the short term or long term.

In the literature, several technical solutions have been proposed to reduce the energy consumption by refrigerated vehicles. However, the impact of parking a refrigerated vehicle under a shed on its heat balance and, consequently, on the volume of consumed energy has not yet been investigated. Moreover, structured knowledge about where these parking sheds should be deployed is missing. These issues were identified as a research gap.

Accordingly, the research questions were formulated as follows:

1. Is it possible to reduce energy consumption by parking a refrigerated vehicle under a shed (e.g., canopy, carport) within parking places in RSAs? What is the scale of savings that can be achieved by applying this solution?

2. Where should the sheds be located along the national road network in Poland?

The aim of this study was to show the impact of sheds (e.g., canopies, carports) used within parking places in RSAs on the energy consumption of refrigerated vehicles.

The article includes a literature review section, where the currently available related literature is analyzed, a methodology section describing basic assumptions, limitations, and the mathematical model used to conduct the research, a results section showing the main outcomes of calculation and the range of savings to be achieved, as well as the proposed locations of RSAs equipped with sheds, and a conclusions and discussion section summing up the research.

\section{Literature Review}

Parking areas are developed as part of road infrastructure [12,13]. Within highways and expressways, RSAs are built as separate areas equipped with car parking lots and infrastructure to ensure comfort and rest for travelers $[14,15]$. These places may be installed with different infrastructures and vary in terms of the services provided [16,17].

The issues related to road infrastructure development for electric vehicle services have been widely discussed in the literature. The locations for charging facilities are proposed with consideration of several aspects $[18,19]$. Csonka and Csiszár analyzed the charging and recharging periods, considering dynamic electricity rates in the smart grid in order to minimize the cost of charging from the user's perspective [20]. Csonka developed an optimization method for static and dynamic charging infrastructure for electric buses to determine the location and capacity of charging units at minimum cost [21]. Iliopoulou and Kepaptsoglou [22] investigated the combined transit route network design and charging infrastructure location problem and proposed a bilevel formulation to handle both planning stages. At the upper level, candidate route sets are generated and evaluated, while, at the lower level, wireless charging infrastructures are deployed optimally. The issues of autonomous vehicle energy consumption and emissions were also addressed $[23,24]$. The concepts of infrastructure for autonomous electric vehicles in urban areas were elaborated by Zhang et al. [25]. Perera et al. [26] proposed a novel framework to estimate multiperiod 
public recharging demands, minimize lifecycle costs, maximize service coverage and infrastructure utilization, and ensure reasonable paybacks compared to conventional planning approaches. An overview of the available studies shows that significant efforts have been undertaken to improve road transport infrastructure; however, these improvements are not related to refrigerated transport operation.

The regulation of driver's working time forces drivers to take breaks during cargo delivery. This obligation applies to vehicles of different types, including refrigerated ones. The driver may have a short break (e.g., 15 or $30 \mathrm{~min}$ ) or long break of up to 24 or $45 \mathrm{~h}[6,27]$. During that time, the refrigeration unit of the vehicle works continuously.

Transport and storage conditions significantly influence the efficiency of the delivery of perishable goods. These conditions are related to the cargo carriage route, the time of year and day, weather conditions, etc. [28]. Importantly, perishable goods may face a deterioration problem; therefore, the assurance of their special transport and storage conditions is strictly required [29].

The issue of reducing energy consumption in refrigerated cargo transport has been widely discussed in the literature [30-34]. Evans et al. [35] used benchmarking surveys to collect data on the performance of chilled, frozen, and mixed (chilled and frozen stores operated from a single refrigeration system) food cold stores to identify the major factors influencing energy consumption. They found that, in the case of cold stores, the store shape (which had a major impact on surface area of the stores), usage, and ambient temperature had a significant impact on energy consumption.

Ambient conditions influence the perishable cargo transport. Changes in ambient air temperature during the day are reflected in the changes in temperature inside the refrigerated vehicle, especially the air directly under the roof. The detrimental influence of weather conditions is noticeable not only during truck driving, but also during the stop periods of the refrigerated vehicle in the parking lot [36]. These conditions affect the heat balance of the vehicle and, thus, the energy consumption of refrigeration unit $[8,28,36,37]$.

The conditions of refrigerated vehicle services, which influence the heat/mass exchange, have also been discussed in studies. Li and Xie [38] noted that drastic changes of interior air temperature and humidity induced by intense heat/mass exchange between inside and outside hinder guaranteeing the quality of perishable food when the door of the refrigerated vehicle is opened. Issues with the heat balance of refrigerated vehicles, air flow inside the refrigerated body of trucks, and influencing factors were investigated in several studies. Moureh and Flick [39] conducted numerical and experimental studies of airflow within a semi-trailer enclosure loaded with pallets. The importance of air ducts in decreasing temperature differences throughout the cargo was shown. It was also noted that monitoring of refrigerated vehicle's parameters via a wireless device can contribute to the reduction in fuel costs [40]. Gaedtke et al. [41] found that the inclusion of vacuum insulation panels can halve the required cooling energy.

Refrigeration was of particular importance to many greenhouse gas or carbon footprinting studies [42]. The influence of ambient temperature, cargo weight, and driving condition on $\mathrm{CO}_{2}$ and $\mathrm{NO}_{\mathrm{X}}$ emissions from refrigerated vans was assessed by Yang et al. [43]. It was found that the overall $\mathrm{CO}_{2}$ emissions of vans with refrigeration units were $15 \%$ higher than those of standard vehicles, with $\mathrm{NO}_{\mathrm{X}}$ emissions estimated to be elevated by $18 \%$.

Attention was also given to the approaches to minimize energy consumption in refrigerated vehicles [44]. For example, lightweight and low-thermal-conductivity material can be applied as the external wall of refrigerated vehicles [45]. It was also highlighted that the usage of aluminum sheets as the external wall of refrigerated vehicles can reduce the longevity of insulation, which increases heat infiltration into the cooling chamber, thereby aggravating energy demand. Qu et al. [46] composed the hierarchy of a comprehensive energy consumption evaluation system that may be applied for food refrigerated transportation.

Ways to increase the efficiency of refrigerated vehicle power systems have also been widely researched. Christodoulou et al. [47] studied the hybridization of refrigerated commercial vehicles by replacing the traditionally used auxiliary diesel engine with a 
nonpolluting, nonelectric unit. Simulation results of Romijn et al. [48] showed that the fuel consumption can be reduced up to $0.52 \%$ by including smart auxiliaries (e.g., climate control system) in energy management. In turn, Marx et al. [3] conducted a comparative analysis of different system architectures for a hybrid fuel cell and battery power source powering a refrigerated semi-trailer.

The technical characteristics of refrigerated trucks have been explored in order to find ways to increase their energy efficiency. Romijn et al. [49] proposed a novel on/off control concept for the control of a refrigerated semi-trailer, the air supply system, and the climate control system. Simulation results on a low-fidelity vehicle model showed the achievable fuel reduction performance. Artuso et al. [2] developed a dynamic model of the insulated box of a refrigerated vehicle to identify the dynamic load and cooling power demand of the truck. The model can be applied to predict the evolution of the internal temperature during long-distance deliveries.

Other solutions have also been suggested to reduce energy consumption in the transport of perishable goods [30,50-52]:

- regular checks on the insulation of refrigerated transport means in order to eliminate deteriorated units;

- temperature profile analysis in the refrigeration chamber;

- $\quad$ optimal location of loads inside the chamber, considering the width of gaps between pallets;

- external humidification of the vehicle, in order to reduce its thermal load, etc.

A lot of attention has also been paid to the service and energy efficiency of refrigerated containers $[53,54]$. It was noted that, depending on the manufacturer of the refrigeration unit of container, its technical conditions, and the temperature level in the chamber, the average power consumption of a standard 40 foot refrigerated container ranges from 6 to $9 \mathrm{~kW}$ [55]. This means that the average daily energy consumption of the container will amount to 144-216 kWh. Fitzgerald et al. [9] studied the energy consumption of refrigerated containers and found that it varies around $\pm 60 \%$.

Shinoda and Budiyanto [30] investigated the effect of roof shade installation covering a reefer container storage yard to protect it from solar insolation. They concluded that the stacking effect of containers provides a thermal benefit to the power consumption of refrigerated containers located on the middle tier and bottom tier [32]. This effect was also noted in $[28,37,56,57]$. However, this approach was not verified in regard to perishable goods transport in refrigerated semi-trailers.

Our systematized literature review revealed that the issue of energy efficiency in road refrigerated transport should be analyzed in more detail to elaborate and introduce new methods for energy consumption reduction. An analysis of the impact of refrigerated vehicle parking under a roof (shed) on its heat balance is missing. Consequently, cost saving opportunities in this context have also not been investigated. Additionally, the potential locations of such parking lots with sheds within the road infrastructure network have not previously been analyzed in detail.

Therefore, our research topic is relevant; specifically, parking refrigerated vehicles under the sheds in order to minimize heat gains through insulation may save a significant amount of energy.

\section{Materials and Methods}

\subsection{Research Methodology and Basic Assumptions}

The methodology used to conduct the research is summarized in Figure 1. In order to estimate the technical and economic effects, a tractor unit with a refrigerated semi-trailer was considered in our investigation. A mathematical model was elaborated to determine the heat balance of the semi-trailer and, consequently, the amount of possible energy savings depending on the operational conditions. 


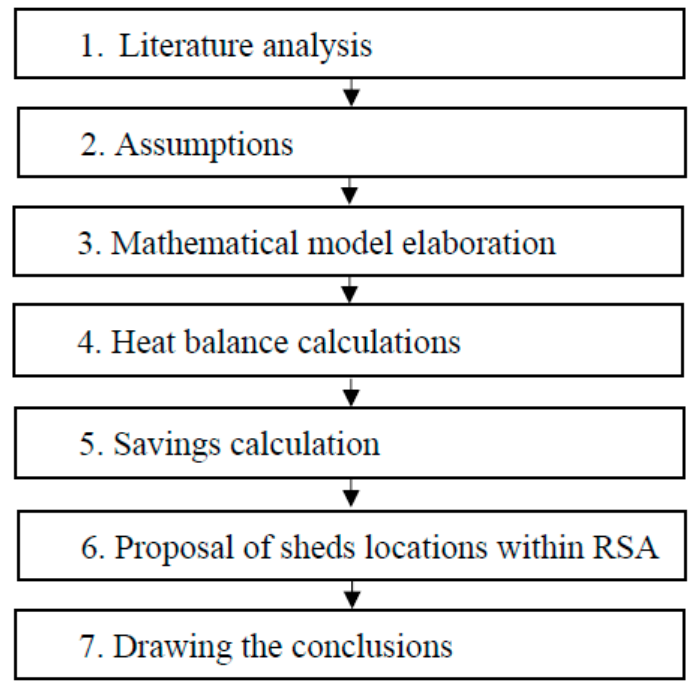

Figure 1. Research methodology.

The following data were needed to develop the computational model:

- dimensions and load capacity of refrigerated semi-trailer;

- selected technical parameters of semi-trailer's refrigeration unit, especially the mode of its operation, the number of internal fans and evaporator heaters, their nominal power, the type of evaporator defrost system, etc.;

- operating conditions of refrigerated semi-trailer, including evaporator daily defrost time;

- the type of transported goods, their thermophysical features, and transport conditions, including temperature and humidity;

- external weather conditions (temperature and relative air humidity, wind speed and direction), the dynamics of these conditions, etc.

The mathematical model is based on several limitations and assumptions, including the following:

- $\quad$ only the set dimensions of refrigerated semi-trailers are considered;

- the semi-trailers are used to transport frozen goods, and the ambient temperature is above freezing point;

- goods are loaded to the semi-trailer in the frozen state and there is no need to chill them;

- the ambient temperature around the semi-trailer is constant and evenly spread across all walls, except walls exposed to insolation;

- the temperature inside the semi-trailer is constant over transport time and is evenly distributed inside the semi-trailer's body;

- for the purpose of calculation, the insulation properties of the semi-trailer are the same across all walls; hence, a constant value of the global heat transfer coefficient of the semi-trailer $k_{g l}=0.4 \mathrm{~W} / \mathrm{m}^{2} \cdot \mathrm{K}$ is assumed;

- disturbances of the linear temperature distribution in the insulation layer in the corners of the refrigerated semi-trailer are taken into account by referencing the process of heat exchange to the geometric mean of the surface $F$;

- the temperature of the four walls of the semi-trailer is assumed to be equal to the ambient temperature;

- the intensity of solar radiation impacting the vehicle is not considered;

- the calculations are carried out for the average daily operational conditions of the semi-trailer.

We carried out calculations and conducted comparative analyses for several variants of the refrigerated semi-trailer locations within the parking place. The developed mathematical model was applied to estimate the savings according to several use cases when using sheds for refrigerated vehicles at RSAs or other parking places. The range of cost 
savings achieved by the decrease in energy consumption of the vehicle's refrigeration unit during the vehicle stopover under the parking shed was also calculated.

Ideal locations of RSAs equipped with sheds along the road transport network in Poland are proposed, and potential savings that could be achieved within the selected infrastructure network were calculated.

\subsection{Mathematical Model}

The energy consumption of a refrigerated semi-trailer depends entirely on the heat load of its body. There is a direct relationship between energy consumption and cold demand in each refrigeration facility. This relation results from the second law of thermodynamics, which can be presented as follows (Equation (1)):

$$
P_{m}=\frac{\dot{Q}_{0}}{\varepsilon}(\mathrm{W}),
$$

where $P_{m}$ is the average $24 \mathrm{~h}$ power consumed by the refrigeration unit of the trailer (semi-trailer) (W), $\dot{Q}_{0}$ is the daily cooling capacity of the refrigeration unit of the trailer (semi-trailer) (W), and $\varepsilon$ is the energy efficiency coefficient of the refrigeration unit.

The $\varepsilon$ coefficient is usually given by the refrigeration unit's manufacturer and depends on the evaporating and condensing temperatures of the refrigerant, which in turn depend on the required temperature inside the refrigerated semi-trailer and the ambient temperature. The $\dot{Q}_{0}$ value can be determined from the heat balance equation of a refrigerated semi-trailer (Equation (2)).

$$
\dot{Q}_{0} \geq \sum_{j=1}^{4} \dot{Q}_{j}
$$

where $\sum_{j=1}^{4} \dot{Q}_{j}$ is the sum of individual components of the heat balance, i.e., the sum of all heat gains (or losses) from various sources (W), and $j$ is the component of the heat balance $(j=1, \ldots, 4)$.

The method of analyzing the influence of ambient factors on a refrigerated semi-trailer carrying a frozen load can be presented in the following form (Equation (3)) [37]:

$$
\dot{Q}_{0}=\dot{Q}_{1}+\dot{Q}_{2}+\dot{Q}_{3}+\dot{Q}_{4}(\mathrm{~W})
$$

where $\dot{Q}_{1}$ represents the heat gains (or losses) through insulation (W), $\dot{Q}_{2}$ is the heat stream due to intended ventilation $(\mathrm{W}), Q_{3}$ is the heat stream from fans installed inside the semi-trailer $(\mathrm{W})$, and $\dot{Q}_{4}$ is the heat stream occurring due to evaporator defrosting $(\mathrm{W})$.

According to Equation (4), the determination of the $\dot{Q}_{1}$ component of the heat balance is based on the sum of heat gains (or losses) through insulation. This stream is calculated as the sum of heat streams flowing into the interior of the refrigerated semi-trailer through all its walls [28].

$$
\dot{Q}_{1}=\sum_{i=1}^{6} \dot{Q}_{1 i}=\sum_{i=1}^{6}\left(k_{i} \cdot F_{i} \cdot \Delta T_{i}\right)(\mathrm{W}),
$$

where $\Delta T_{i}=T_{z i}-T_{w i}$ is the temperature difference between the ambient temperature $T_{z}$ and the temperature inside the semi-trailer $T_{w}$ in relation to the individual walls of the semi-trailer $(\mathrm{K})(i=1, \ldots, 6), F_{i}$ is the heat exchange area of the semi-trailer wall $\left(\mathrm{m}^{2}\right)$ $(i=1, \ldots, 6), k_{i}$ is the semi-trailer wall heat transfer coefficient $\left(\mathrm{W} /\left(\mathrm{m}^{2} \cdot \mathrm{K}\right)\right)(i=1, \ldots, 6)$, and $i$ is the wall number of the refrigerated semi-trailer $(i=1, \ldots, 6)$.

The abbreviations $t_{o t}\left({ }^{\circ} \mathrm{C}\right)$ for ambient temperature and $t_{t}\left({ }^{\circ} \mathrm{C}\right)$ for cargo transport temperature are used in the text to allow calculations in degrees Celsius.

Considering the set assumptions and limitations, the area $F$ can be defined as the geometric mean (Equation (5)) [28].

$$
F=\sqrt{F_{z} \cdot F_{w}}\left(\mathrm{~m}^{2}\right)
$$


where $F_{z}$ is the external surface of the semi-trailer $\left(\mathrm{m}^{2}\right)$, and $F_{w}$ is the internal surface of the semi-trailer $\left(\mathrm{m}^{2}\right)$.

According to standards [58,59], the influence of insolation, when calculating the heat balance of a chamber, should be taken into account assuming that the ultraviolet radiation causes the surface to be heated above the ambient temperature (for bright vertical surfaces by $12 \mathrm{~K}$; for bright horizontal surfaces by $16 \mathrm{~K}$ ). For these surfaces, Equation (4) may be presented as follows (Equations (6) and (7)) [28]:

- for a vertical sunlit surface,

$$
\dot{Q}_{1 \Sigma}=k_{g l} \cdot \sqrt{F_{z} \cdot F_{w}} \cdot\left(T_{z}+12-T_{w}\right)(\mathrm{W}) ;
$$

- for a horizontal sunlit surface,

$$
\dot{Q}_{1 \Sigma}=k_{g l} \cdot \sqrt{F_{z} \cdot F_{w}} \cdot\left(T_{z}+16-T_{w}\right)(\mathrm{W}) .
$$

It should be taken into account that insolation does not last $24 \mathrm{~h}$ a day. Moreover, the intensity of radiation varies depending on the sunlight angle. When calculating the heat balance of a refrigerated semi-trailer, this fact is usually not considered. However, it should be noted that external temperature measurements carried out for refrigerated containers transported on ships [60] showed that, during the most intense hours of insolation, these temperatures could reach the level of $75-80{ }^{\circ} \mathrm{C}(348.15-353.15 \mathrm{~K})$. The same situation is observed during the operation of refrigerated vehicles, including semi-trailers. Therefore, the values recommended by the standards $[58,59] \Delta T_{n}=12 \mathrm{~K}$ and $16 \mathrm{~K}$ can be treated as daily averages for the heaviest operating conditions of the semi-trailers.

The heat balance component $\dot{Q}_{2}$ characterizes the heat stream due to intended ventilation. This stream also depends on the temperatures $T_{z}$ and $T_{w}$ and can be determined using Equation (8) [28,37].

$$
\dot{Q}_{2}=n_{p} \cdot V \cdot\left(\rho_{z} \cdot h_{z}-\rho_{w} \cdot h_{w}\right) \cdot \frac{1}{3.6} \cdot \frac{1}{24}(\mathrm{~W}),
$$

where $n_{p}$ is the number of air exchanges inside the semi-trailer (1/day), $V$ is the volume of the semi-trailer $\left(\mathrm{m}^{3}\right), \rho_{z}$ is the density of ambient air $\left(\mathrm{kg} / \mathrm{m}^{3}\right), h_{z}$ is the enthalpy of ambient $\operatorname{air}(\mathrm{kJ} / \mathrm{kg}), \rho_{w}$ is the air density inside the semi-trailer $\left(\mathrm{kg} / \mathrm{m}^{3}\right)$, and $h_{w}$ is the enthalpy of air inside the semi-trailer $(\mathrm{kJ} / \mathrm{kg})$.

Considering that $h=c_{p} \cdot T$ [60], Equation (8) can be written as follows [28]:

$$
\dot{Q}_{2}=n_{p} \cdot V \cdot\left(\rho_{z} \cdot c_{p z} \cdot T_{z}-\rho_{w} \cdot c_{p w} \cdot T_{w}\right) \cdot \frac{1}{3.6} \cdot \frac{1}{24}(\mathrm{~W}),
$$

where $c_{p z}$ is the specific heat capacity of ambient air $(\mathrm{kJ} / \mathrm{kg} \cdot \mathrm{K})$, and $c_{p w}$ is the specific heat capacity of air inside the semi-trailer $(\mathrm{kJ} / \mathrm{kg} \cdot \mathrm{K})$.

The heat balance also includes the $\dot{Q}_{3}$ component that presents that heat stream coming from the fans working in the refrigerated semi-trailer. This stream is practically independent of $T_{z}$ and $T_{w}$; therefore, in the calculations, it can be treated as a constant value. Two cases may be considered:

- there is no need to defrost the evaporator, the fans in the chamber work $24 \mathrm{~h}$ a day:

$$
\dot{Q}_{3}=N_{w} \cdot P_{w}(\mathrm{~W})
$$

- there is a need to defrost the evaporator, where, during the defrosting process, the fans are turned off:

$$
\dot{Q}_{3}=N_{w} \cdot P_{w} \cdot \frac{24-\tau_{o d}}{24}(\mathrm{~W}),
$$


where $N_{w}$ is the number of fans in the semi-trailer (pcs), $P_{w}$ is the nominal power consumed by one fan $(\mathrm{W})$, and $\tau_{o d}$ is the time for defrosting the evaporator every day (h) (as a rule, the calculation takes the total defrost time of $1 \mathrm{~h}$ per day, i.e., $\tau_{o d}=1$ ).

The heat stream $\dot{Q}_{4}$ generated by evaporator defrosting in a simplified manner can be determined according to Equation (12), assuming a defrosting efficiency $\eta_{o d}=0.2-0.3$ [61] and taking into account the operating conditions of the semi-trailer.

$$
\dot{Q}_{4}=N_{g} \cdot P_{g} \cdot \frac{\tau_{o d}}{24} \cdot\left(1-\eta_{o d}\right)(W),
$$

where $N_{g}$ is the number of heaters in the semi-trailer (pcs), $P_{g}$ is the power consumed by one heater $(\mathrm{W})$, and $\eta_{o d}$ is the defrosting efficiency.

Figure 2 presents a block diagram of the algorithm to determine potential savings in energy consumption of a refrigerated vehicle, considering the elimination of solar impact by equipping the parking place with shed.

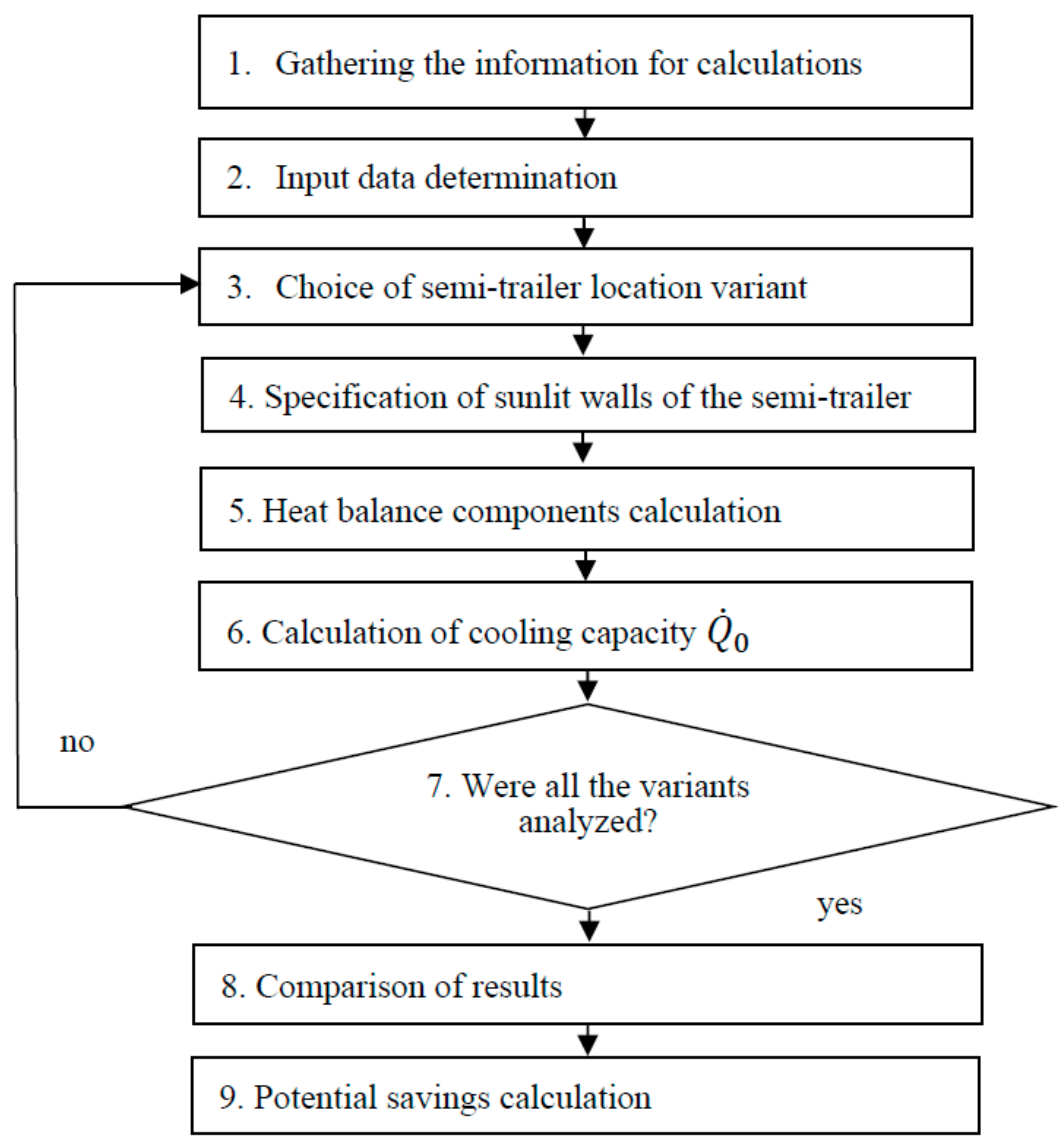

Figure 2. A simplified algorithm to determine the total heat loads to evaluate the savings associated with the energy consumption.

In order to determine the average $24 \mathrm{~h}$ cooling capacity $\dot{Q}_{0}$, calculations were performed taking into account the selected operating conditions of the refrigerated semi-trailer. By comparing the calculations results for different settings, it was possible to determine the differences in heat loads and, thus, the amount of potential savings.

The energy consumption of the refrigeration unit of the semi-trailer during its supply consists of the consumption by individual elements, including machines (e.g., compressor, pump, fans, etc.). To estimate the value of energy savings for the refrigeration unit of a semi-trailer as a result of roofing of the parking place, the percentage reduction in heat load $\dot{Q}_{0}$ should be divided by the energy efficiency coefficient of the unit $\varepsilon$. For modern 
models of units, it is recommended to adopt the value of $\varepsilon=1.2-2$ when transporting frozen cargoes.

\section{Results}

\subsection{Calculation Results}

In order to estimate the roofing influence on the reduction in energy consumption by the refrigeration unit of a semi-trailer, a comparative analysis of the heat balances of the semi-trailer in different locations within an RSA parking place was carried out. The following locations of the semi-trailer were analyzed (Figure 3), including parking:

(a) without roofing;

(b) under a shed, when the sun reaches one side wall of the semi-trailer;

(c) under a shed, eliminating the influence of insolation.
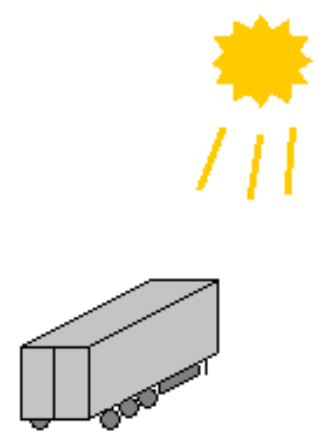

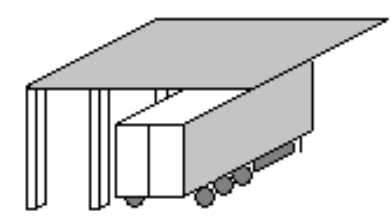

$\mathrm{b}$
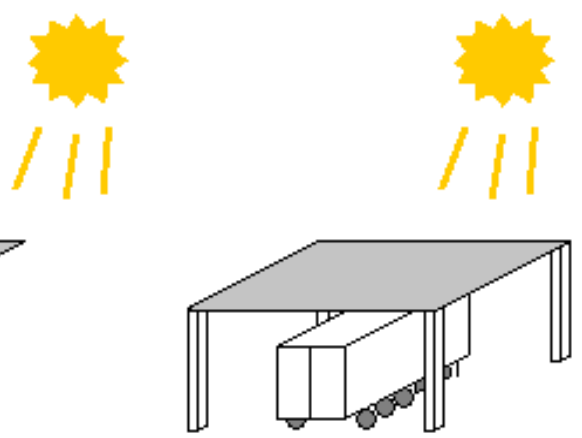

C

Figure 3. Location of the refrigerated semi-trailer, where (a) semi-trailer is parked without roofing, influenced by insolation, (b) semi-trailer is parked under a shed, with the sun reaching one side wall of the semi-trailer, and (c) semi-trailer is parked under a shed that eliminates the influence of insolation.

The input data used to conduct calculations are shown in Tables 1 and 2.

Table 1. Heat exchange surface of the exemplary refrigerated semi-trailer.

\begin{tabular}{cccc}
\hline Walls of Refrigerated & External Surface, & Internal Surface, & Calculated (Geometric Mean), \\
Semi-Trailer & $\boldsymbol{F}_{\boldsymbol{z}}\left(\mathbf{m}^{\mathbf{2}}\right)$ & $\boldsymbol{F}_{\boldsymbol{w}}\left(\mathbf{m}^{\mathbf{2}}\right)$ & $\boldsymbol{F}$ \\
\hline Side walls & $38.22 \times 2$ & $34.62 \times 2$ & 72.75 \\
Floor, roof & $35.36 \times 2$ & $32.76 \times 2$ & 68.07 \\
Door, rear & $7.31 \times 2$ & $6.40 \times 2$ & 13.68 \\
Total & 161.78 & 147.56 & 154.50 \\
\hline
\end{tabular}

The calculations were carried out in accordance with the algorithm presented in Section 3 (Figure 3). The results are summarized in Table 3. Results show that location of the refrigerated semi-trailer within the parking place in an RSA has a significant impact on the energy consumption of its unit. The location of the refrigerated semi-trailer in RSA under a shed (Figure 4c), compared to its location in a parking place without roofing (Figure 4a), allows reducing the average daily power consumed by the semi-trailer's refrigeration unit by $12.03 \%$. However, the achieved $\dot{Q}_{1}$ reduction is about $16.65 \%$. It can be stated that parking refrigerated vehicles in the shade under a roof, as well as equipping parking places with sheds (or canopies, etc.), is beneficial. 
Table 2. Input data for calculations of semi-trailer heat balance.

\begin{tabular}{lc}
\hline \multicolumn{1}{c}{ Parameter } & Value \\
\hline Cargo & Frozen meat \\
Mass, $m_{l}$ (tons) & 20 \\
Cargo transportation temperature, $t_{t}\left({ }^{\circ} \mathrm{C}\right)$ & -18 \\
Ambient temperature, $t_{o t}\left({ }^{\circ} \mathrm{C}\right)$ & 16 \\
Semi-trailer's heat transfer coefficient, $k_{g l}\left(\mathrm{~W} / \mathrm{m}^{2} \cdot \mathrm{K}\right)$ & 0.4 \\
Semi-trailer's volume, $V\left(\mathrm{~m}^{3}\right)$ & 85.16 \\
Density of the ambient air, $\rho_{z}\left(\mathrm{~kg} / \mathrm{m}^{3}\right)$, & 1.22 \\
Enthalpy of ambient air, $h_{z}(\mathrm{~kJ} / \mathrm{kg})$ & 24.6 \\
Air density inside the semi-trailer, $\rho_{w}\left(\mathrm{~kg} / \mathrm{m}^{3}\right)$ & 1.38 \\
Enthalpy of the air inside the semi-trailer, $h_{w}(\mathrm{~kJ} / \mathrm{kg})$ & -16.80 \\
Number of air changes inside the semi-trailer, $n_{p}(1 / \mathrm{day})$ & 2 \\
Number of fans in the semi-trailer, $N_{w}(\mathrm{pcs})$ & 3 \\
Nominal power consumed by one fan, $P_{w}(\mathrm{~W})$ & 250 \\
Number of heaters in semi-trailer, $N_{g}(\mathrm{pcs})$ & 2 \\
Power consumed by one heater, $P_{g}(\mathrm{~W})$ & 2000 \\
Total evaporator defrosting time during the day, $\tau_{o d}(\mathrm{~h})$ & 1 \\
Aggregate energy efficiency index, $\varepsilon$ & 1.5 \\
\hline
\end{tabular}

Table 3. The results of heat load calculations and the average daily power consumed by the refrigeration unit of a semi-trailer in different parking locations.

\begin{tabular}{|c|c|c|c|c|}
\hline $\begin{array}{l}\text { Location of the Refrigerated } \\
\text { Semi-Trailer }\end{array}$ & $\begin{array}{c}\text { Heat Gain Through } \\
\text { Insulation, } \\
\dot{Q}_{1}(\mathrm{~W})\end{array}$ & $\begin{array}{l}\text { Total Heat Gains, } \\
\dot{Q}_{0}(\mathrm{~W})\end{array}$ & $\begin{array}{c}\text { Average Daily Power } \\
\text { Consumed, } \\
P_{m}(\mathrm{~W})\end{array}$ & $\begin{array}{l}\text { Relative Change in } \\
\qquad P_{m}(\%)\end{array}$ \\
\hline $\begin{array}{l}\text { Without roofing, influenced by } \\
\text { insolation (Figure 4a) }\end{array}$ & 2554.1 & 3534 & 2356 & - \\
\hline $\begin{array}{l}\text { Under a shed, with the sunlight on } \\
\text { one side wall of the semi-trailer } \\
\text { (Figure } 4 \mathrm{~b} \text { ) }\end{array}$ & 2303.5 & 3283.3 & 2188.9 & -7.09 \\
\hline $\begin{array}{l}\text { Under a shed that eliminates the } \\
\text { influence of insolation (Figure } 4 \mathrm{c} \text { ) }\end{array}$ & 2128.8 & 3108.7 & 2072.5 & -12.03 \\
\hline
\end{tabular}

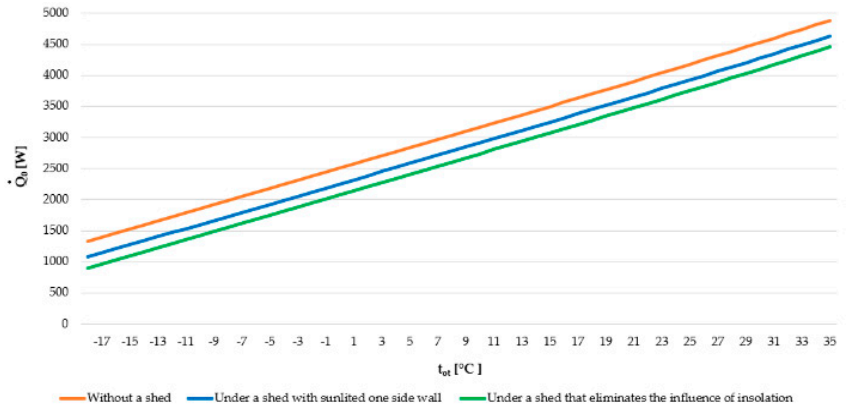

(a)

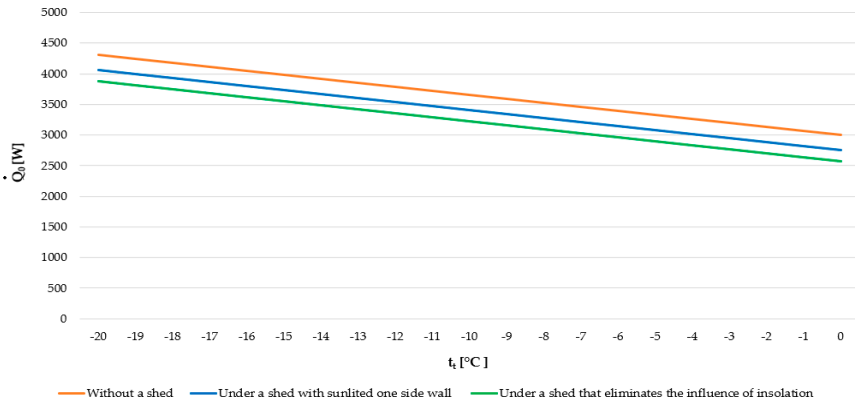

(b)

Figure 4. The dependence of the total heat gains on the ambient temperature (a) and cargo transportation temperature $(\mathbf{b})$ for the given operational conditions of the refrigerated semi-trailer.

The dependence of the total heat gains on the ambient temperature for the given operational conditions of the refrigerated semi-trailer for analyzed variants is shown in Figure $4 \mathrm{a}$. In the case when the ambient temperature is constant $\left(t_{o t}=16^{\circ} \mathrm{C}\right)$, the total heat gains vary depending on the frozen cargo transportation temperature $t_{t}$. The dependence of the total heat gains on the cargo transportation temperature for the given operating conditions of the refrigerated semi-trailer is shown in Figure $4 \mathrm{~b}$. 
Using the developed approach, it was possible to calculate the total heat gains for the given operational conditions of the refrigerated semi-trailer considering the average month ambient temperature during the year in Szczecin city (Poland) [62] (Figure 5). Our proposed approach also can be used to assess total heat gains during summer and winter periods. The calculation results conducted for the average daily temperature fluctuation observed in July 2021 and January 2022 [63] in Szczecin city are shown in Figures 6 and 7.

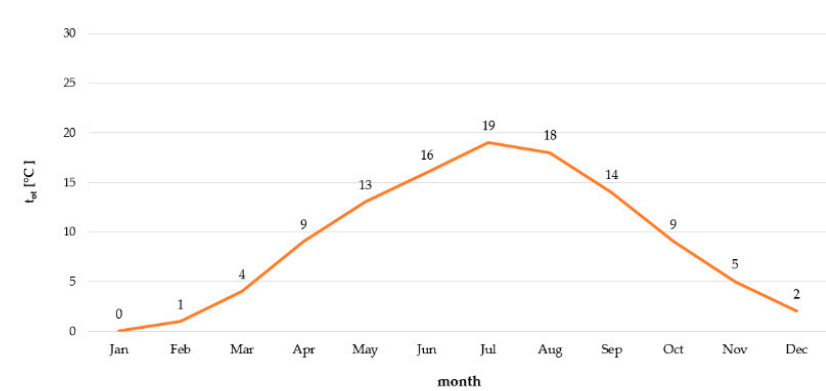

(a)

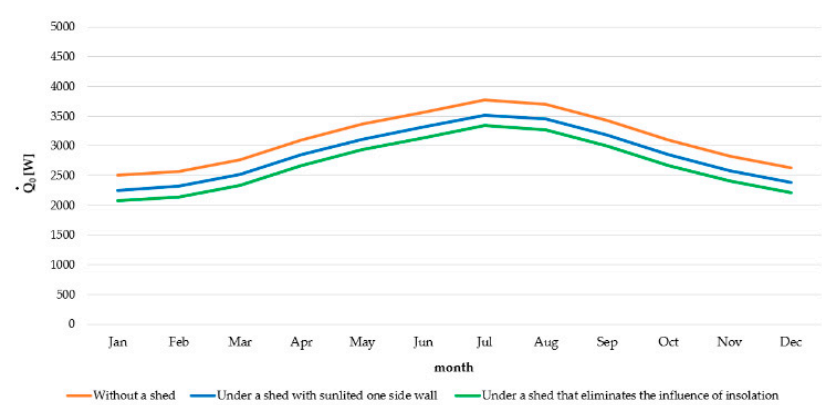

(b)

Figure 5. The average ambient temperature fluctuation during the year in Szczecin city (a) and dependence of daily total heat gains of the refrigerated semi-trailer on the ambient temperature in particular months (b).

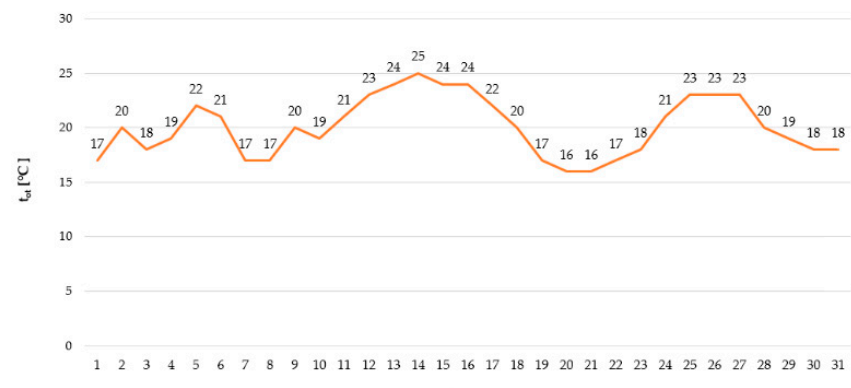

day

(a)

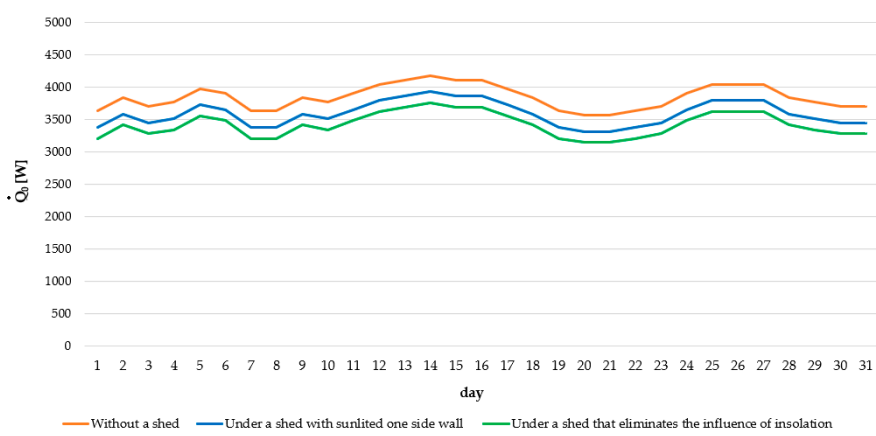

(b)

Figure 6. The average ambient temperature fluctuation in July 2021 in Szczecin city (a) and dependence of daily total heat gains of the refrigerated semi-trailer on the ambient temperature in particular days in July (b).

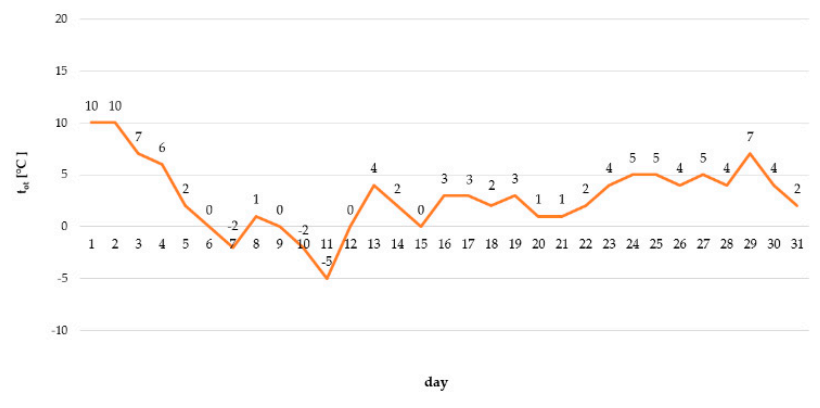

(a)

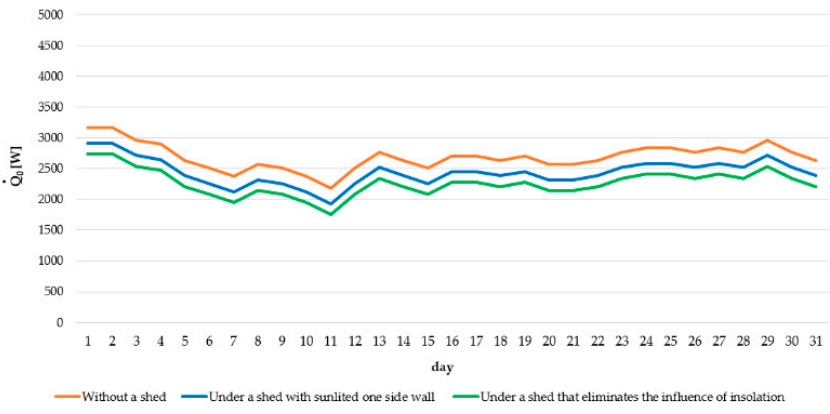

(b)

Figure 7. The average ambient temperature fluctuation in January 2022 in Szczecin city (a) and dependence of daily total heat gains of the refrigerated semi-trailer on the ambient temperature in particular days in January (b). 


\subsection{Simulation of Parking Sheds Locations-Case Study of Poland}

In order to show the scale of potential savings that may come from using the parking sheds in a wider context, the case study of Poland was analyzed. In Poland, RSAs are located along the road infrastructure of highways and expressways [64]. According to the data of the General Directorate for National Roads and Motorways [65], in December 2021, there were 356 parking areas within the road transport network in Poland. These include private facilities (77 elements) and RSAs of classes I, II, and III (279 elements) (Table 4). A total of 10,179 parking places for trucks are available within the mentioned facilities.

Table 4. RSA classes in Poland (own elaboration based on $[17,65]$ ).

\begin{tabular}{|c|c|c|c|}
\hline RSA Class & Function & Equipment & $\begin{array}{l}\text { Number of RSAs along } \\
\text { Road Network }\end{array}$ \\
\hline I & Recreation & $\begin{array}{c}\text { Equipped with parking spaces (parking), } \\
\text { maneuvering lanes, rest and sanitary } \\
\text { facilities, and lighting; RSA can be } \\
\text { equipped with catering facilities }\end{array}$ & 154 \\
\hline II & Leisure and services & $\begin{array}{l}\text { Equipped with the facilities available at } \\
\text { RSA I, in addition to petrol stations, vehicle } \\
\text { service stations, catering and commercial } \\
\text { facilities, and tourist information facilities }\end{array}$ & 100 \\
\hline III & $\begin{array}{l}\text { Recreational function } \\
\text { and service }\end{array}$ & $\begin{array}{l}\text { Equipped with the facilities available at } \\
\text { RSA II, in addition to accommodation } \\
\text { facilities, as well as post offices, banks, } \\
\text { tourist offices, and insurance offices, } \\
\text { depending on the need. }\end{array}$ & 25 \\
\hline
\end{tabular}

RSAs are equipped with different infrastructure elements, including [65] parking lots for passenger cars, trucks, and buses, toilets, petrol stations, restaurants, accommodation, stations for charging electric vehicles, security, fencing, monitoring, lighting, places for vehicles with dangerous goods, car washes, vehicles repair shops, and liquid waste discharge points. This does not include sheds that may be used by refrigerated vehicles. The infrastructure of class III RSAs in Poland is summarized in Table 5.

Determining ideal shed locations along the road transport network in Poland should begin with class III RSAs because the most developed services are available there. Then, the sheds may be installed within class II and I RSAs, as well as other parking places.

The number of parking lots under the roofing may depend on the number of the available parking places for trucks or the cargo transport intensity along the route.

It is also proposed to install sheds in class III RSAs. The simulation of RSA locations equipped with sheds is shown in Figure 8. RSA Żarska Wieś Północ, and Żarska Wieś Połud., as well as Kępnica and Zastawie, are located on opposite sides of the roads.

We assessed the transport companies' energy savings resulting from parking the refrigerated vehicles under the sheds available at class III RSAs in Poland. We assumed the following:

- the refrigeration unit of the vehicle consumes on average 1.5-3 L of fuel per hour (depending on refrigerated vehicle's state and ambient conditions);

- $\quad$ one liter of fuel costs 1.3 EUR;

- frozen cargo is transported in the refrigerated vehicle;

- refrigerated vehicles are parked under sheds during the summer period (e.g., June-August);

- it is possible to achieve an $8 \%$ reduction in power consumed during sunlit hours (average value);

- insolation influences the refrigerated vehicle at parking places for $6 \mathrm{~h}$ per day (worst scenario compared to the analysis in Section 4.1). 
Table 5. Infrastructure of class III RSAs in Poland (own elaboration based on [65]).

\begin{tabular}{|c|c|c|c|c|c|c|c|c|c|c|c|c|c|c|c|c|c|c|}
\hline$\dot{\mathbf{z}}$ & 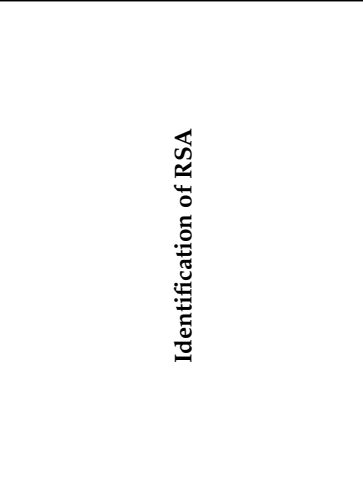 & 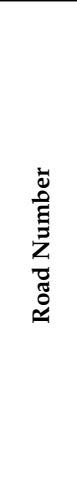 & 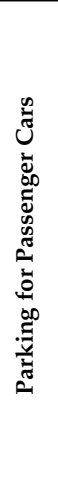 & 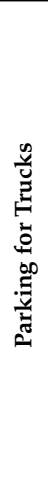 & 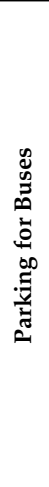 & $\frac{\stackrel{0}{0}}{\frac{\pi}{0}}$ & 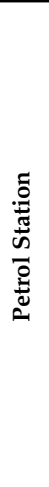 & 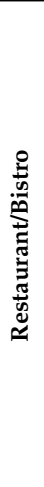 & 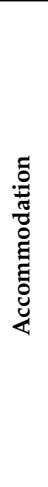 & 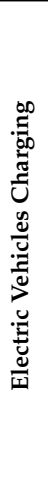 & 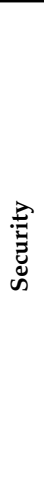 & 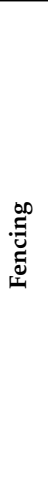 & 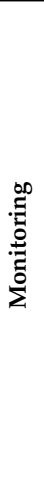 & & 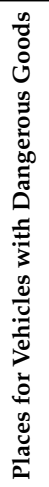 & 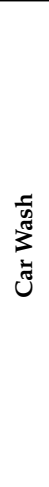 & 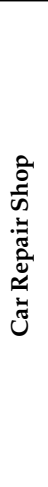 & 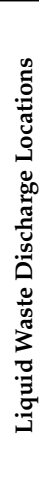 \\
\hline 1 & MOP III Wieszowa Północ & A1c & 169 & 81 & 2 & $+*$ & + & + & + & - & - & + & + & + & + & - & + & + \\
\hline 2 & MOP III Mszana Północ & A1a & 161 & 21 & 6 & + & + & + & + & - & - & + & + & + & + & - & + & + \\
\hline 3 & MOP III Wirek & A4 & 99 & 48 & 0 & + & + & + & + & - & - & + & + & + & + & - & - & + \\
\hline 4 & MOP III Kępnica & $\mathrm{A} 4$ & 50 & 50 & 0 & + & + & + & + & + & - & + & + & + & + & + & - & + \\
\hline 5 & MOP III Zastawie & A4 & 50 & 30 & 0 & + & + & + & + & + & - & + & + & + & + & + & - & + \\
\hline 6 & MOP III Morawica & $\mathrm{A} 4$ & 50 & 24 & 0 & + & + & + & + & + & - & + & + & + & + & + & - & + \\
\hline 7 & MOP Janów Lubelski Wschód & S19 & 154 & 35 & 8 & + & - & - & - & - & - & + & + & + & + & - & - & + \\
\hline 8 & MOP III Krzyżanów Wschód & $\mathrm{A} 1$ & 80 & 31 & 10 & + & + & + & - & + & - & + & + & + & + & - & + & + \\
\hline 9 & MOP III Wiśniowa Góra Zachód & A1 & 116 & 20 & 4 & + & + & + & - & - & - & + & + & + & + & - & - & + \\
\hline 10 & MOP III Chrzastów & A2 & 158 & 55 & 0 & + & + & + & + & - & - & + & + & + & + & - & + & + \\
\hline 11 & MOP III Nowostawy & $\mathrm{A} 2$ & 226 & 60 & 25 & + & + & + & + & - & - & + & + & + & + & - & + & + \\
\hline 12 & MOP III Młyński Staw & $\mathrm{A} 4$ & 190 & 62 & 5 & + & + & + & + & - & + & + & + & + & + & - & + & + \\
\hline 13 & MOP III Wysoka & $\mathrm{A} 4$ & 158 & 33 & 0 & + & + & + & + & + & + & + & + & + & + & - & + & + \\
\hline 14 & MOP III Police & $\mathrm{A} 2$ & 33 & 37 & 4 & + & + & + & + & - & - & + & + & + & + & - & + & + \\
\hline 15 & MOP III Wilkowice & S5f & 39 & 28 & 4 & + & + & + & + & - & + & + & - & + & + & + & + & + \\
\hline 16 & MOP III Palikówka & $\mathrm{A} 4$ & 57 & 31 & 0 & + & + & + & + & - & - & + & + & + & + & - & - & + \\
\hline 17 & MOP III Wysoka Wschód & S3 & 87 & 25 & 3 & + & + & + & + & - & + & + & + & + & + & - & - & + \\
\hline 18 & MOP III Żabia Wola & S8 & 90 & 54 & 5 & + & + & + & + & - & - & + & - & + & + & - & - & + \\
\hline 19 & MOP III Żarska Wieś Północ & $\mathrm{A} 4$ & 80 & 58 & 3 & + & + & + & + & - & - & + & + & + & + & + & + & + \\
\hline 20 & MOP III Żarska Wieś Połud. & $\mathrm{A} 4$ & 80 & 73 & 5 & + & + & + & + & - & - & + & + & + & + & - & + & + \\
\hline 21 & MOP III Kraśnik Dolny & $\mathrm{A} 4$ & 55 & 52 & 3 & + & + & + & + & - & - & + & + & + & + & - & + & + \\
\hline 22 & MOP III Oleśnica Mała & $\mathrm{A} 4$ & 82 & 47 & 3 & + & + & + & + & - & + & + & + & + & + & - & + & + \\
\hline 23 & MOP III Morzęcino Wschód & S5 & 159 & 51 & 8 & + & + & + & - & - & + & + & + & + & + & - & - & + \\
\hline 24 & MOP III Wisznia Mała Zachód & S5 & 95 & 44 & 7 & + & - & + & - & - & + & + & + & + & + & - & - & + \\
\hline 25 & MOP III Trzebiel & DK18 & 40 & 10 & 0 & + & + & + & + & - & + & + & - & + & - & - & - & - \\
\hline
\end{tabular}

*' + ' means that the infrastructure is available; ' - ' means that the infrastructure is unavailable.

Considering our assumptions, the transport companies' savings for one vehicle can reach 0.16-0.36 EUR per hour or 0.96-2.16 EUR per $6 \mathrm{~h}$ of daily stoppage.

These savings can be considered as insignificant for one stoppage; however, taking into account the scale effect, the benefits become more visible, including the reduction in emissions.

We made the following assumptions:

- a total number of 1060 parking spaces are available for trucks at selected class III RSAs;

- the number of lots with sheds in particular RSAs constitute $10 \%$ of the parking spaces for trucks (i.e., a total number of 106 parking spaces with sheds);

- $50 \%$ of these lots are used daily for $6 \mathrm{~h}$ (53 parking lots).

Considering these assumptions, the daily savings can reach 50.88-114.48 EUR, with monthly (31 days) savings of 1577.28-3548.88 EUR.

The effect of roofing at parking places on refrigerated vehicles would be more significant during the summer period, especially in southern countries (e.g., Portugal, Spain, Italy, Greece, and Turkey), where the ambient temperature is higher than in Poland and the sun shines for a long time. 


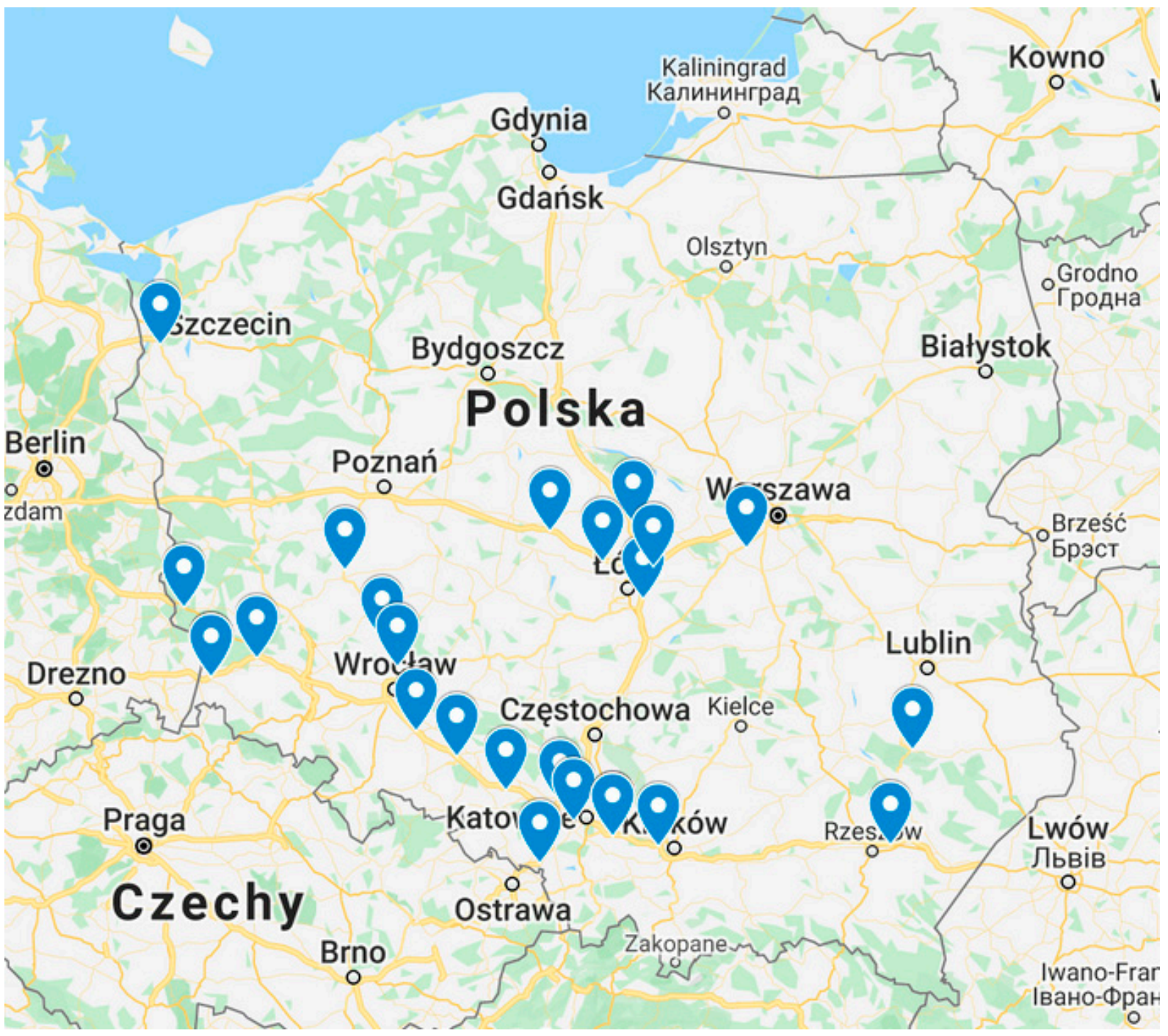

Figure 8. Proposal of ideal locations of RSAs equipped with sheds along the motorways and expressways in Poland.

\section{Conclusions and Discussion}

The article presented a novel approach for addressing the energy efficiency in road refrigerated transport. The solution to equip RSAs with sheds was investigated. We elaborated a methodology to calculate the potential savings in road refrigerated transport and then revealed the impact of parking sheds (e.g., canopies and carports) within rest and service areas on the energy consumption of the semi-trailer's refrigeration unit. We found that the location of a truck under a shed, during the driver's break, can influence the heat balance of the vehicle carrying perishable cargoes and, consequently, the energy consumed.

We fill the research gap with our results and show the scale of potential savings that may be achieved due to parking under a shed. The study contributes to deepening the knowledge related to energy efficiency issues in road refrigerated transport.

Therefore, it is recommended to install sheds in parking places for refrigerated vehicles. These sheds may be installed as fixed equipment. However, mobile (e.g., automatically controlled) or manually operated solutions may also be applied. These specific parking spaces can be additionally equipped with plugs to connect the refrigeration units to electric energy [36], which can also limit emissions while vehicles' refrigeration units are operated. Consequently, these improved infrastructure elements may constitute the basic equipment for refrigerated vehicles within rest and service areas. 
We carried out calculations with special regard for the conditions of frozen cargo transport when applying the developed mathematical model. The analysis of semi-trailer locations demonstrated that the roofing of a parking space can reduce energy consumption by up to $12.03 \%$, thus achieving significant savings considering the scale of perishable cargo transport. Considering the fact that research results regarding the influence of parking sheds on the heat balance of refrigerated semi-trailers are lacking, our results may be compared to those related to refrigerated container storage at storage yards. According to Shinoda and Budiyanto [30], the location of refrigerated containers in a bay under a roof may lead to energy savings of up to $12.76 \%$ (for selected storage conditions). This result is comparable to the result achieved in our study.

The validity of these results is limited by the assumptions and simplifications introduced for the simulations. In real conditions, fluctuation of the ambient temperature during the day is observed, in addition to variation of the time spent by refrigerated vehicles in a parking place (from 15 min up to $45 \mathrm{~h}$ ).

Our results may be of interest to transport and forwarding companies with perishable products. The results may facilitate their decision-making process in selecting the appropriate parking place for the refrigerated vehicle within RSAs or other locations. The developed mathematical model can be included in a decision-making software related to calculations of potential energy consumption savings.

Moreover, the research outcomes may have industrial implications and be useful for the institutions responsible for road infrastructure design, as they clearly show the need to implement the recommended special equipment (roofing, sheds). Research results may also be useful for national or regional infrastructure development policies.

The directions of our future research cover further investigations of refrigerated transport energy efficiency issues focusing on technical and organizational solutions to achieve savings and to reduce the negative impact of transport on the environment. We will also focus on computational model development, considering different conditions of refrigerated vehicle operation. One of these conditions is the solar radiation intensity impacting the vehicle under various shading conditions. We would also like to compare our results to experimental ones collected in real time. Additionally, a complex methodology to determine the location of sheds within an RSA considering several operational and economic criteria will be developed. We will also consider developing the management system of refrigerated vehicles (including the connection of vehicle refrigeration units to electricity) within RSAs. The construction of sheds at parking places will be analyzed in detail to determine the optimal shape and technical specifications (considering opportunities for installing photovoltaic panels on the top of the shed).

Author Contributions: Conceptualization, L.F.-D.; methodology, L.F.-D.; software, L.F.-D.; validation, L.F.-D. and C.C.; formal analysis, L.F.-D.; investigation, L.F.-D. and C.C.; resources, L.F.-D.; data curation, L.F.-D.; writing-original draft preparation, L.F.-D.; writing-review and editing, C.C.; visualization, L.F.-D.; supervision, L.F.-D.; project administration, L.F.-D.; funding acquisition, L.F.-D. All authors have read and agreed to the published version of the manuscript.

Funding: This research received no external funding. The APC was funded by the West Pomeranian University of Technology in Szczecin.

Institutional Review Board Statement: Not applicable.

Informed Consent Statement: Not applicable.

Data Availability Statement: Not applicable.

Acknowledgments: The authors would like to acknowledge the West Pomeranian University of Technology in Szczecin for APC funding.

Conflicts of Interest: The authors declare no conflict of interest. The funders had no role in the design of the study; in the collection, analyses, or interpretation of data; in the writing of the manuscript, or in the decision to publish the results. 


\section{References}

1. Road Freight Transport by Type of Goods. Available online: https://ec.europa.eu/eurostat/statistics-explained/index.php?title= Road_freight_transport_by_type_of_goods\&oldid=549207\#Road_freight_transport_by_type_of_goods_.28NST_classifications. 29 (accessed on 26 December 2021).

2. Artuso, P.; Rossetti, A.; Minetto, S.; Marinetti, S.; Moro, L.; Col, D.D. Dynamic modeling and thermal performance analysis of a refrigerated truck body during operation. Int. J. Refrig. 2019, 99, 288-299. [CrossRef]

3. Marx, N.; Hissel, D.; Harel, F.; Pahon, E.; Courteille, B.; Chaillou, F. On the design of a hybrid fuel cell—Battery genset for a refrigerated semi-trailer truck. In Proceedings of the 2018 IEEE Vehicle Power and Propulsion Conference, Chicago, IL, USA, 27-30 August 2018.

4. Artuso, P.; Rossetti, A.; Minetto, S.; Marinetti, S.; Del Col, D. Numerical investigation on the thermal performance of a new cooling unit for refrigerated transport using $\mathrm{CO}_{2}$ as the working fluid. In Proceedings of the 8th Conference on Ammonia and $\mathrm{CO}_{2}$ Refrigeration Technology, Ohrid, North Macedonia, 11-13 April 2019. [CrossRef]

5. Motor Transport Institute. Available online: http://www.its.waw.pl (accessed on 4 April 2014).

6. Directive 2002/15/EC of the European Parliament and of the Council of 11 March 2002 on the Organisation of the Working Time of Persons Performing Mobile Road Transport Activities. Available online: https://eur-lex.europa.eu/legal-content/EN/TXT/ ?uri=celex:32002L0015 (accessed on 20 February 2022).

7. Emission Factors for Transporting Food Worldwide as of 2018, by Selected Modes of Transport. Available online: https: / / www.statista.com/statistics/1253773/food-freight-transport-emission-factors-by-mode (accessed on 26 December 2021).

8. Accorsi, R.; Gallo, A.; Manzini, R.A. Climate driven decision-support model for the distribution of perishable products. J. Clean. Prod. 2017, 165, 917-929. [CrossRef]

9. Fitzgerald, W.B.; Howitt, O.J.; Smith, I.J.; Hume, A. Energy use of integral refrigerated containers in maritime transportation. Energy Policy 2011, 39, 1885-1896. [CrossRef]

10. Spengler, T.; Wilmsmeier, G. Energy consumption and energy efficiency indicators in container terminals-A national inventory. In Proceedings of the IAME 2016 Conference, Hamburg, Germany, 23-26 August 2016.

11. Wilmsmeier, G.; Froese, J.; Zotz, A.K.; Meyer, A. Energy consumption and efficiency: Emerging challenges from reefer trade in South American container terminals. FAL Bull. 2014, 329, 1-17.

12. Jacyna, M.; Wasiak, M.; Lewczuk, K.; Chamier-Gliszczyński, N.; Dąbrowski, T. Decision problems in developing proecological transport system. Rocz. Ochr. Srodowiska 2018, 20, 1007-1025.

13. Kostrzewski, M.; Varjan, P. The issue of parking areas conditions in surrounding of logistics and production facilities in Slovakia and Poland. In Proceedings of the International Conference Transport Means 2018, Trakai, Litwa, 3-5 October 2018; pp. 791-796.

14. Jacyna, M.; Semenov, I.N.; Trojanowski, P. The research directions of increase effectiveness of the functioning of the RSA with regard to specialized transport. Arch. Transp. 2015, 35, 27-39. [CrossRef]

15. Semenov, I.; Filin, S.; Trojanowski, P.; Jacyna, M. Modernizacja MOP w zakresie przystosowania do obsługi samochodów-chłodni (eng A comprehensive modernization of Parking Lots focused to a refrigerated—Trucks services). Logistyka 2015, 4, 907-914. (In Polish)

16. Filina-Dawidowicz, L.; Heinrich, P.; Filin, S. Koncepcja sieci miejsc specjalistycznej obsługi samochodów-chłodni na terenie Polski (eng. Concept of a network of places for specialized service of refrigerated vehicles in Poland. Case study). Stud. Przypadku. Autobusy Tech. Eksploat. Syst. Transp. 2017, 1-2, 59-65. (In Polish)

17. Obwieszczenie Ministra Infrastruktury I Budownictwa z dnia 23 Grudnia 2015 r. w Sprawie Ogłoszenia Jednolitego Tekstu Rozporządzenia Ministra Transportu i Gospodarki Morskiej w Sprawie Warunków Technicznych, Jakim Powinny Odpowiadać Drogi Publiczne i ich Usytuowanie. WARSZAWA, dnia 29 Stycznia 2016 r. Poz. 124. Available online: http:/ /isap.sejm.gov.pl/ isap.nsf/download.xsp/WDU20160000124/O/D20160124.pdf (accessed on 25 December 2021).

18. Gkatzoflias, D.; Drossinos, Y.; Zubaryeva, A.; Zambelli, P.; Dilara, P.; Thiel, C.H. Optimal Allocation of Electric Vehicle Charging Infrastructure in Cities and Regions. Available online: https:/ / publications.jrc.ec.europa.eu/repository/bitstream/JRC101040/ allocatechargingpoints_sciencepolreport_eurreport_online.pdf (accessed on 26 December 2021).

19. Karolemeas, C.; Tsigdinos, S.; Tzouras, P.G.; Nikitas, A.; Bakogiannis, E. Determining Electric Vehicle Charging Station Location Suitability: A Qualitative Study of Greek Stakeholders Employing Thematic Analysis and Analytical Hierarchy Process. Sustainability 2021, 13, 2298. [CrossRef]

20. Csonka, B.; Csiszár, C. Integrated information service for plug-in electric vehicle users including smart grid functions. Transport 2019, 34, 135-145. [CrossRef]

21. Csonka, B. Optimization of Static and Dynamic Charging Infrastructure for Electric Buses. Energies 2021, 14, 3516. [CrossRef]

22. Iliopoulou, C.; Kepaptsoglou, K. Integrated transit route network design and infrastructure planning for on-line electric vehicles. Transp. Res. Part D Transp. Environ. 2019, 77, 178-197. [CrossRef]

23. He, Y.; Csiszár, C. Model for Crowdsourced Parcel Delivery Embedded into Mobility as a Service Based on Autonomous Electric Vehicles. Energies 2021, 14, 3042. [CrossRef]

24. Torok, A.; Derenda, T.; Zanne, M.; Zoldy, M. Automatization in road transport: A review. Prod. Eng. Arch. 2018, 20, 3-7. [CrossRef]

25. Zhang, H.; Sheppard, C.J.R.; Lipman, T.E.; Zeng, T.; Moura, S.J. Charging infrastructure demands of shared-use autonomous electric vehicles in urban areas. Transp. Res. Part D Transp. Environ. 2020, 78, 102210. [CrossRef]

26. Perera, P.; Hewage, K.; Sadiq, R. Electric vehicle recharging infrastructure planning and management in urban communities. $J$. Clean. Prod. 2020, 250, 119559. [CrossRef] 
27. European Agreement Concerning the Work of Crews of Vehicles Engaged in International Road Transport (AETR), Done at Geneva on 1 July 1970 (Consolidated Text, Version 2006, Document ECE/TRANS/SC.1/2006/2). Available online: http: / / www.unece.org/trans/main/sc1/sclaetr.html (accessed on 26 December 2021).

28. Filina-Dawidowicz, L. Wspomaganie Podejmowania Decyzji w Zakresie Kompleksowej Obsługi Kontenerów Chłodniczych w Zintegrowanych Łańcuchach Transportowych; Oficyna Wydawnicza Politechniki Warszawskiej: Warszawa, Poland, 2018. (In Polish)

29. Postan, M.; Filina-Dawidowicz, L. Dynamic Optimization Model for Planning of Supply, Production, and Transportation of Perishable Product. In Sustainable Transport Development, Innovation and Technology. TranSopot 2016. Springer Proceedings in Business and Economics; Suchanek, M., Ed.; Springer: Cham, Switzerland, 2017. [CrossRef]

30. Shinoda, T.; Budiyanto, M.A. Energy Saving Effect of Roof Shade for Reefer Container in Marine Container Terminal. J. Jpn. Inst. Navig. 2016, 134, 103-113. [CrossRef]

31. Omara, A.A.M.; Mohammedali, A.A.M. Thermal management and performance enhancement of domestic refrigerators and freezers via phase change materials: A review. Innov. Food Sci. Emerg. Technol. 2020, 66, 102522. [CrossRef]

32. Budiyanto, M.A.; Shinoda, T. Stack Effect on Power Consumption of Refrigerated Containers in Storage Yards. Int. J. Technol. 2017, 8, 1182-1190. [CrossRef]

33. Tassou, S.A.; De-Lille, G.; Ge, Y.T. Food transport refrigeration-Approaches to reduce energy consumption and environmental impacts of road transport. Appl. Therm. Eng. 2009, 29, 1467-1477. [CrossRef]

34. Zakrzewski, B.; Filin, S.; Konieczny, P. An analysis of energy consumption in refrigerated cargo sea transport. Pol. Marit. Res. 2000, 4, 25-32

35. Evans, J.A.; Foster, A.; Huet, J.M.; Reinholdt, L.; Fikiin, K.; Zilio, C.; Houska, M.; Landfeld, A.; Bond, C.; Scheurs, M.; et al. Specific energy consumption values for various refrigerated food cold stores. Energy Build. 2013, 74, 141-151. [CrossRef]

36. Filin, S.; Filina-Dawidowicz, L.; Procak, M. Energooszczędność a redukcja kosztów samochodowego transportu chłodniczego (eng. Energy efficiency and cost reduction of refrigerated truck transport). Chłodnictwo 2016, 1-2, 44-52. (In Polish)

37. Filina-Dawidowicz, L.; Filin, S. Innovative energy-saving technology in refrigerated containers transportation. Energy Effic. 2019, 12, 1151-1165. [CrossRef]

38. Li, J.; Xie, R. Influence factors of air-temperature increasing within refrigerated trucks during door-opening state. Nongye Jixie Xuebao/Trans. Chin. Soc. Agric. Mach. 2014, 45, 254-259. [CrossRef]

39. Moureh, J.; Flick, D. Airflow pattern and temperature distribution in a typical refrigerated truck configuration loaded with pallets Int. J. Refrig. 2004, 27, 464-474. [CrossRef]

40. Gajewska, T.; Lorenc, A. The impact of trailer conditions on the quality of refrigerated food transport services-A case study. Transp. Probl. 2019, 14, 97-107. [CrossRef]

41. Gaedtke, M.; Wachter, S.; Kunkel, S.; Sonnick, S.; Rädle, M.; Nirschl, H.; Krause, M.J. Numerical study on the application of vacuum insulation panels and a latent heat storage for refrigerated vehicles with a large Eddy lattice Boltzmann method. Heat Mass Transf./Waerme Stoffuebertragung 2020, 56, 1189-1201. [CrossRef]

42. Alamoush, A.S.; Ballini, F.; Olcer, A.I. Ports' technical and operational measures to reduce greenhouse gas emission and improve energy efficiency: A review. Mar. Pollut. Bull. 2020, 160, 111508. [CrossRef]

43. Yang, Z.; Tate, J.E.; Morganti, E.; Shepherd, S.P. Real-world $\mathrm{CO}_{2}$ and $\mathrm{NO}_{\mathbf{X}}$ emissions from refrigerated vans. Sci. Total Environ. 2021, 763, 142974. [CrossRef]

44. Adamski, B. Pobór Energii Elektrycznej Przez Agregaty Chłodnicze (eng. Electricity Consumption by Refrigeration Units). Rynek Instal. 2008, 9, 1-13. Available online: http:/ / www.rynekinstalacyjny.pl/artykul/id3249, pobor-energii-elektrycznej-przezagregaty-chlodnicze?print $=1$ (accessed on 25 September 2021).

45. Adekomaya, O.; Jamiru, T.; Sadiku, R.; Huan, Z. Minimizing energy consumption in refrigerated vehicles through alternative external wall. Renew. Sustain. Energy Rev. 2017, 67, 89-93. [CrossRef]

46. Qu, R.-G.; Liu, G.-H.; Xie, R.-H.; You, L. Establishment and Application of Comprehensive Energy-Consumption Evaluation System for Food Refrigeration Transportation. In New Energy and Sustainable Development, Proceedings of the 2016 International Conference on New Energy and Sustainable Development (NESD 2016), Changsha, China, 19-20 March 2016; Yuan, Y.-P., Ed.; World Scientific Publishing Company: Singapore, 2017; pp. 172-178. [CrossRef]

47. Christodoulou, F.; Sechenyh, V.; Zhao, H.; Garner, C.P.; Clarke, H. Performance of a novel liquid nitrogen power system. Appl. Therm. Eng. 2021, 191, 116896. [CrossRef]

48. Romijn, T.C.J.; Donkers, M.C.F.; Kessels, J.T.B.A.; Weiland, S. A Distributed Optimization Approach for Complete Vehicle Energy Management. IEEE Trans. Control. Syst. Technol. 2019, 27, 964-980. [CrossRef]

49. Romijn, C.; Donkers, T.; Kessels, J.; Weiland, S. Real-time distributed economic model predictive control for complete vehicle energy management. Energies 2017, 10, 1096. [CrossRef]

50. Jedermann, R.; Geyer, M.; Praeger, U.; Lang, W. Sea transport of bananas in containers-Parameter identification for a temperature model. J. Food Eng. 2013, 115, 330-338. [CrossRef]

51. Reducing Heat Absorption of Reefer Containers, Lowering Energy Consumption since 2014. Available online: http://www. braintrustbase.com/sites/default/files/upload-grafik/uploads/merged_document_7.pdf (accessed on 20 April 2017).

52. Sørensen, K.K.; Skovrup, M.J.; Jessen, L.M.; Stoustrup, J. Modular modeling of a refrigeration container. Int. J. Refrig. 2015, 55, 17-29. [CrossRef] 
53. Filina-Dawidowicz, L.; Gajewska, T. Examination of importance and range of comprehensive service for refrigerated containers in seaports. Int. J. Appl. Manag. Sci. 2018, 10, 26-43. [CrossRef]

54. Castelein, B.; Geerlings, H.; Van Duin, R. The reefer container market and academic research: A review study. J. Clean. Prod. 2020, 256, 120654. [CrossRef]

55. Reefer Container Power Consumption. Available online: http://www.ship.ru/konteyners/40_cube.php (accessed on 6 April 2017).

56. Budiyanto, M.A.; Shinoda, T. Thermal simulation of the effect of solar radiation on the temperature increases on the refrigerated container walls. Int. J. Sustain. Eng. 2021, 14, 1229-1238. [CrossRef]

57. van Duin, J.H.R.; Geerlings, H.; Tavasszy, L.A.; Bank, D.L. Factors causing peak energy consumption of reefers at container terminals. J. Shipp. Trade 2019, 4, 1-17. [CrossRef]

58. Standards PN-91/W-75051; Klimatyzacja i wentylacja pomieszczeń mieszkalnych na statkach. Założenia projektowe i metody obliczeń (eng. Air Conditioning and Ventilation of Living Quarters on Ships. Design Assumptions and Calculation Methods). Polski Komitet Normalizacyjny: Warsaw, Poland, 1991. (In Polish)

59. Standards PN-EN ISO 7547:2006; Statki i technika morska. Klimatyzacja i wentylacja pomieszczeń mieszkalnych. Założenia projektowe i podstawy obliczeń (eng. Ships and Marine Technology. Air Conditioning and Ventilation of Living Quarters. Design Assumptions and Basis of Calculations). Polski Komitet Normalizacyjny: Warsaw, Poland, 2006. (In Polish)

60. Михеев, М.А.; Михеева, И.М. Основы теплопередачи; Энергия: Москва, Russia, 1973. (In Russian)

61. Zakrzewski, B.; Haberek, J. Badanie termiczne kontenerów chłodzonych 1C (eng. Thermal test of refrigerated containers 1C). Chtodnictwo 1994, 3, 23-27. (In Polish)

62. Available online: https://pogoda.wp.pl/pogoda-dlugoterminowa/szczecin/3083829 (accessed on 18 February 2022).

63. Available online: https://weather.com/pl-PL/pogoda/miesieczne/1/dc3eb4353758a8ea3370b0a2c623a946ec456749aa0436eb4 6ced75b3164c0a0 (accessed on 18 February 2022).

64. Road Infrastructure Map. Available online: https://www.nik.gov.pl/plik/id,17590.pdf (accessed on 24 December 2021).

65. General Directorate for National Roads and Motorways. List of Parking Lots and RSA. Available online: https://www.gov.pl/ web/gddkia/wykaz-parkingow-i-mop (accessed on 29 December 2021). 